\title{
Detection of Dirofilaria immitis using microscopic, serological and molecular techniques among dogs in Cabo Frio, RJ, Brazil
}

\author{
Detecção de Dirofilaria immitis utilizando técnicas microscópicas, \\ imunológicas e moleculares em cães de Cabo Frio, RJ \\ Taíssa Angélica Lemos Trancoso"; Nathália da Conceição Lima; Alynne Silva Barbosa; \\ Daniela Leles ${ }^{1}$; Ana Beatriz Monteiro Fonseca²; Norma Vollmer Labarthe ${ }^{3}$; \\ Otilio Machado Pereira Bastos ${ }^{1}$; Claudia Maria Antunes Uchôa ${ }^{1}$ (D) \\ ${ }^{1}$ Departamento de Microbiologia e Parasitologia, Instituto Biomédico, Universidade Federal Fluminense - UFF, Rio de \\ Janeiro, RJ, Brasil \\ ${ }^{2}$ Departamento de Estatística, Universidade Federal Fluminense - UFF, Niterói, RJ, Brasil \\ ${ }^{3}$ Fundação Oswaldo Cruz - FIOCRUZ, Rio de Janeiro, RJ, Brasil
}

How to cite: Trancoso TAL, Lima NC, Barbosa AS, Leles D, Fonseca ABM, Labarthe NV, Bastos OMP, Uchôa CMA. Detection of Dirofilaria immitis using microscopic, serological and molecular techniques among dogs in Cabo Frio, RJ, Brazil. Braz J Vet Parasitol 2020; 29(1): e017219. http://doi.org/10.1590/S1984-29612020009

\begin{abstract}
Heartworm disease is a health problem for dogs and cats, especially in tropical and subtropical coastal regions of the world. Some studies have compared the efficacy of the diagnostic techniques used to detect this parasitosis. Therefore, the aim of this study was to compare parasitological optical microscopy (POM), serological and molecular techniques for diagnosing canine heartworm infection. Samples were collected between July 2015 and April 2016 from 103 dogs in Cabo Frio, RJ, Brazil. The wet fresh blood, thick smears, thin smears and modified Knott's test were used to detect microfilariae. ELISA (Snap ${ }^{\mathrm{TM}} 4 \mathrm{Dx}{ }^{\circledR}$ IDEXX) was used to detect antigens and the polymerase chain reaction (PCR) was used to detect DNA and enable sequencing for species differentiation and confirmation. $19.4 \%$ of samples were positive according to microscopy. Through PCR, $15.5 \%$ of the total were positive. Using ELISA, the positivity rate was $29.1 \%$. Occult heartworm infection was detected in $11.6 \%$ of the samples. ELISA sensitivity was shown to be higher than PCR or microscopy $(P=0.001)$. Sequencing of samples confirmed the presence of Dirofilaria immitis and Acanthocheilonema reconditum. ELISA was more effective for serological diagnosis canine heartworm and should be used in clinical and epidemiological studies.
\end{abstract}

Keywords: Dogs, thick smear, modified Knott, ELISA, PCR, heartworm.

\section{Resumo}

A dirofilariose é um problema de saúde para cães e gatos, especialmente nas regiões costeiras tropicais e subtropicais do mundo. Alguns estudos compararam a eficácia das técnicas de diagnóstico usadas para detectar esta parasitose. Portanto, o objetivo deste estudo foi comparar a microscopia óptica (OM), técnicas sorológicas e moleculares para o diagnóstico de infecção por Dirofilaria immitis. Foram coletadas, entre julho de 2015 e abril de 2016, amostras de 103 cães em Cabo Frio, RJ, Brasil. O exame direto, distensão espessa, distensão delgada e o teste de Knott modificado foram usados para detectar microfilárias. O ELISA (Snap ${ }^{\text {TM }}$ 4Dx ${ }^{\circledR}$ IDEXX) foi usado para

\footnotetext{
Received October 7, 2019. Accepted January 14, 2020.
}

Financial support: Funding was received from the National Council for Research and Technological Development (Conselho Nacional de Pesquisa e Desenvolvimento Tecnológico, CNPq), the "Carlos Chagas Filho" Research Support Foundation of the State of Rio de Janeiro (Fundação Carlos Chagas Filho de Amparo à Pesquisa do Estado do Rio de Janeiro, FAPERJ) and the Pro-Rectorate for Research and Innovation of the Fluminense Federal University (Pró-reitoria de Pesquisa e Inovação da Universidade Federal Fluminense, PROPPI-UFF).

Corresponding author: Claudia Maria Antunes Uchôa. E-mail: claudiauchoa@id.uff.br 
detectar antígenos e a reação em cadeia da polimerase (PCR) foi usada para detectar DNA e o sequenciamento para diferenciação e confirmação de espécie. Das amostras, 19,4\% foram positivas de acordo com a microscopia. Por PCR, 15,5\% do total foram positivos. Utilizando o ELISA, a taxa de positividade foi de 29,1\%. Dirofilariose oculta foi detectada em 11,6\% das amostras. A sensibilidade ao ELISA mostrou-se superior à $P C R$ ou microscopia $(P=0,001)$. O sequenciamento das amostras confirmou a presença de Dirofilaria immitis e Acanthocheilonema reconditum. O ELISA foi mais eficaz no diagnóstico sorológico de dirofilariose canina e deve ser usado em estudos clínicos e epidemiológicos.

Palavras-chave: Cães, distensão espessa, Knott modificado, ELISA, PCR, dirofilariose.

\section{Introduction}

Dirofilaria immitis, the canine heartworm, is an important filarial nematode that typically inhabits the right ventricle and pulmonary arteries of its hosts. It can cause infections in dogs, cats, wild canids, ferrets and sea lions. Its accidental hosts include horses, bears and primates such as humans and orangutans. The heartworm parasite is transmitted by various mosquitoes of the genera Culex, Aedes, Anopheles and Ochlerotatus (McCall et al., 2008).

The clinical signs, when present, are caused through progressive vascular physical injury that is induced by the adult worms. As the lesions become severe, the right ventricle is enlarged, the circulatory system loses the ability to compensate and right heart failure becomes present. The typical clinical signs include chronic cough, dyspnea, exercise intolerance and loss of weight (McCall et al., 2004). In humans, infection with D. immitis can cause impairment of the lung parenchyma. The parasite does not complete its life cycle, and the immature forms of the worm die in the branches of the pulmonary arteries, thus forming pulmonary lesions that can often be misdiagnosed radiologically as primary or metastatic pulmonary tumors (Duran-Struuck et al., 2005).

The prevalence of canine heartworm disease varies according to the geographical location, mosquito population, unprotected canine population, number of microfilaremic dogs, diagnostic technique used, age, hair coat length, predominant hair color and lifestyle, travel and management of the animals. Some authors have shown that as dogs grow older, their chances of becoming infected increase. Thus, the highest infection rate observed was among 3 to 6-year-old dogs (Montaño et al., 2002; Labarthe et al., 2014).

The incidence of infected animals in coastal areas is thought to be higher due to the richness and abundance of vectors. In Brazil, canine heartworm disease has been described in 15 hyperendemic foci and is present in all regions of the country (Labarthe et al., 2014). In the state of Rio de Janeiro, before the first chemoprophylaxis was used in Brazil, a survey using the modified Knott's test (Newton \& Wright, 1956) showed a prevalence of $16.85 \%$ (134/795), i.e. $8.61 \%$ of the dogs in Rio de Janeiro municipality and $21.76 \%$ in the municipality of Niterói and its surroundings (Labarthe et al., 1997). Years later, after chemoprophylaxis was launched in Brazil, canine heartworm infections became rare (2\%), even when antigen tests were used at former hyperendemic areas (Labarthe et al., 2003). After 2010, the prevalence started to increase again and an updating survey conducted in the lakes region of the eastern coast of the state of Rio de Janeiro (within the coastal lowlands mesoregion), which includes the municipalities of Araruama, Cabo Frio, Iguaba, São Pedro da Aldeia and Arraial do Cabo, showed that antigen frequencies of 27.5\% (11/40) and 62.2\% (23/37) were observed in Cabo Frio and Armações dos Búzios, respectively (Labarthe et al., 2014).

The laboratory diagnosis of dirofilariasis in live animals is made through identification of microfilariae or through antigen detection in blood samples. The general recommendation for screening and diagnosis is that both methods should be used, especially because up to $30 \%$ of the dogs will not develop microfilaremia, in a situation known as "occult infection" (Labarthe et al., 1997; McCall et al., 2008).

The commercially available $D$. immitis antigen tests reliably identify infections with more than one female adult parasite and are nearly $100 \%$ specific. Differences in sensitivity exist, 
especially in cases with low worm burdens and/or low antigenemia (Atkins, 2003; Fernandes et al., 1999). These antigen tests are also used to verify the success of adulticidal therapy and can be performed after five months of the therapy (Fernandes et al., 1999). Because microfilariae can survive after adults die, a small percentage of dogs may present microfilaremia without adult forms in the heart or pulmonary vasculature. Pups from bitches with high microfilarial rates may present transient microfilaremia, due to transplacental passage of these immature forms (Todd \& Howland, 1983). However, the serological test for detection of adult filariid antigens is efficient for ruling out these animals, as false positives (Fernandes et al., 1999; Dillon et al., 2007).

Rishniw et al. (2006) proposed a method for identification of filariids that infect dogs using a PCR technique with several specific primers for the different filariid species. These primers were designed from the $\mathrm{COI}$ (cytochrome oxidase subunit 1) gene for genotypic validation of the species. These authors concluded that PCR developed using panfilarial genes was a suitable tool for genotyping all members of the family Onchocercidae. They suggested that if confirmation was needed, specific-species PCR or amplicon sequencing could be performed, but they took the view that simple gel electrophoresis would be sufficient to make the species-level diagnosis in most cases. PCR targeted to the ITS2 region of the rDNA of filarial worms showed lower prevalence than what was shown through the ELISA test $\left(\mathrm{Snap}^{\mathrm{TM}} 4 \mathrm{Dx} \mathrm{x}^{\circledR}\right)$ and was associated with occult infection or possible failure of DNA extraction (Borthakur et al., 2015). These authors concluded that use of the modified Knott's concentration technique along with the ELISA antigen detection test confirmed the sensitivity of these techniques whereas PCR was confirmed to be valid for identification of canine microfilariae.

Considering these data, the aim of the present study was to compare different techniques for diagnosing canine heartworm infections, with identification of the frequency of infection and its association with gender and age.

\section{Methods}

\section{Sample collection}

One hundred and three blood samples from dogs of various breeds, including males and females, with an age range of 1 to 17 years, that had been admitted to the Cabo Frio Veterinary Clinic, located in the municipality of Cabo Frio, in the lakes region of the state of Rio de Janeiro, Brazil (latitude: -22.8787; longitude: -42.0199; i.e. 22 52' 43" South, 42 1' 12" West.) Sampling was done according to convenience. Blood samples were collected between July 2015 and April 2016. Approximately $3 \mathrm{ml}$ of blood were collected with EDTA and stored at $4{ }^{\circ} \mathrm{C}$ until processing; and $1 \mathrm{ml}$ was collected without EDTA and centrifuged, from which the serum was stored at $-20^{\circ} \mathrm{C}$ until processing. Survey forms were used to record epidemiological data such as age and sex, along with information provided by the owners. Dogs doing dirofilarial prophylaxis were excluded. This study was approved by our institution's animal ethics committee (CEUA-UFF), under license number 168.

\section{Microscopic parasitological techniques}

Wet fresh blood slides (WFB) were made using $40 \mu \mathrm{l}$ of each EDTA sample, soon after collection and presence of microfilariae was verified indirectly through erythrocyte movement caused by the characteristic serpentine movements of these microfilariae (De Carli, 2001). Thin smear slides (TNS) were made through deposition of $10 \mu$ of EDTA whole blood from each sample and stained with Giemsa (Reagen ${ }^{\circledR}$ ) (De Carli, 2001). For thick smear slides (TS), also known as thick-droplet slides, $40 \mu \mathrm{l}$ of EDTA whole blood from each sample were deposited on a glass microscope slide and spread across a small surface area to form a thick drop of about $2 \mathrm{~cm}^{2}$. It was stained with Giemsa (Reagen ${ }^{\circledR}$ ) for 
20 minutes (De Carli, 2001). The modified Knott's test (Knott, 1939; Newton \& Wright, 1956)

(MK) was performed as described by De Carli (2001) and López et al. (2012).

\section{Serological analyses}

The serological diagnosis was made using the ELISA commercial test kit (SNAP 4Dx, IDEXX Laboratories, Maine, USA; ref. 9926193; batch SNEM788), following the manufacturer's recommendations.

\section{DNA extraction for controls and samples}

As positive controls for the reaction were used DNA from an adult specimen of Dirofilaria immitis was extracted using a commercial kit $\left(\right.$ Promega $^{\circledR}$ ), following the manufacturer's instructions and DNA extracted from microfilaremic EDTA whole blood samples. As negative control was used DNA from whole blood from negative dogs (amicrofilaremic and with negative ELISA tests) extracted using the Roche ${ }^{\circledR}$ High Pure PCR Template preparation kit (ref. 11796828001; batch: 14545100) in accordance with the manufacturer's guidelines. DNA from all samples to be tested were extracted using the Roche ${ }^{\circledR}$ High Pure PCR Template preparation kit (ref. 11796828001; batch: 14545100) in accordance with the manufacturer's guidelines.

\section{Polymerase Chain Reaction (PCR)}

PCR was performed using the primer pairs 5 -AGTGTAGAGGGTCAGCCTGAGTTA-3 forward and 5 -ACAGGCACTGACAATACCAAT-3 reverse, to amplify a 203 bp mitochondrial cytochrome oxidase (COI) gene sequence (Rishniw et al., 2006, Simsek et al., 2011), with an increase in the concentration of the primer $(250 \mathrm{mM})$. The PCR was run with a final volume of $20 \mu \mathrm{l}$ and contained $10 \mu \mathrm{l}$ of $200 \mu \mathrm{M}$ GoTaq Green Master Mix (Promega ${ }^{\circledR}$ ), $0.5 \mu \mathrm{l}$ of each primer at a concentration of $250 \mathrm{mM}, 1 \mu \mathrm{l}$ of extracted DNA and $8 \mu \mathrm{l}$ of distilled water to make up to the final volume. The reactions were carried out in a thermocycler using the following protocol: a pre-denaturation stage of $94^{\circ} \mathrm{C}$ for $2 \mathrm{~min}, 32$ denaturation cycles of $94{ }^{\circ} \mathrm{C}$ for $30 \mathrm{~s}$ each, an annealing cycle at $63^{\circ} \mathrm{C}$ for $30 \mathrm{~s}$, an extension cycle at $72{ }^{\circ} \mathrm{C}$ for $30 \mathrm{~s}$ and a final extension cycle at $72{ }^{\circ} \mathrm{C}$ for $7 \mathrm{~min}$ (Simsek et al., 2011).

Aliquots of $8 \mu \mathrm{l}$ of the amplified products were subjected to horizontal electrophoresis on 1.5\% agarose gel in TBE buffer (9 mM Tris-borate and 1 mM EDTA, at pH 8.6; Ambion ${ }^{\circledR}$ ). The electrophoretic run was performed in an electrophoretic tub at $80 \mathrm{~V}$ for $40 \mathrm{~min}$ and then $70 \mathrm{~V}$ for $20 \mathrm{~min}$. A molecular weight marker of 50 base pairs (Promega ${ }^{\circledR}$ ) was used to determine the size of the amplified products. Next, the gel was stained in ethidium bromide for $20 \mathrm{~min}$ and the products were viewed under an ultraviolet transilluminator and photographed. A visible band of $203 \mathrm{bp}$ from the PCR was considered to be a potentially positive result.

For samples that presented positive microscopic parasitological results and negative PCR, another PCR (PCR2) was performed, which included $1 \mu \mathrm{l}$ of the solution containing DNA extracted from the adult parasite to evaluate the presence of inhibitors. In the case of amplification, another PCR (PCR3) was performed with twice the sample volume $(2 \mu \mathrm{l})$, thus increasing the chance of finding parasite DNA. After this procedure, if the sample remained negative, another DNA extraction was performed and PCR was repeated. The samples that remained negative were then processed by means of PCR (PCR4) using a panfilarial primer to investigate possible occurrence of another filariid species. The primer pairs DIDR F (AGT GCG AAT TGC AGA CGC ATT GAG) and DIDR R (AGC GGG TAA TCA CGA CTG AGT TGA) were used, as described by Rishniw et al. (2006). 


\section{Sequencing of amplified PCR products}

The amplified fragments from the adult parasite and from blood samples from four dogs were subjected to sequencing. The amplified PCR products were purified on Wizard ${ }^{\circledR}$ SV Gel and in a PCR Clean-Up System column (Promega ${ }^{\circledR}$ ), followed by direct nucleotide sequencing using the Big Dye Terminator commercial kit v. 1 (Cycle Sequencing Ready Reaction Kit; Applied Biosystems ${ }^{\circledR}$ ). The sequences were edited and analyzed using the Chromas 2.1.1 and Bioedit 7.1.9 software. After editing, the sequences were compared with those available in GenBank, through using the Blast tool (NCBI), available at https://blast.ncbi.nlm.nih.gov/Blast.cgi. It was not possible to carry out sequencing on all the samples due to financial limitations.

\section{Statistical analyses}

The results from using these techniques were analyzed by the McNemar test $(P<0.05)$ and Fisher's exact test. The concordance of results among the different techniques was evaluated by the kappa concordance index (Landis \& Koch, 1977). All the statistical analyses were performed with the aid of the SPSS ${ }^{\circledR}$ version 17 software.

\section{Results}

A total of 20 samples (20/103; 19.4\%) were microfilaremic, and 11 were amicrofilaremic despite being antigenemic. Therefore, $30.1 \%$ of the dogs were found to be infected. The age group with the highest number of infected animals was one to three years of age, comprising 15 animals, and this group presented a statistically significant difference in relation to the other groups $(P=0.0082)$. Out of the 103 animals, $59(55.3 \%)$ were male and $44(44.7 \%)$ were female. The positivity rate was higher among males, but without any statistically significant difference in distribution between the sexes $(P=0.238)($ Table 1$)$.

Table 1. Canine filariids detection using four microscopic parasitological techniques, PCR and ELISA, from 130 dog blood samples obtained in Cabo Frio, RJ, Brazil.

\begin{tabular}{ccccc}
\hline Age & $\begin{array}{c}\text { MALE } \\
+/ \text { total }(\%)\end{array}$ & $\begin{array}{c}\text { FEMALE } \\
+/ \text { total (\%) }\end{array}$ & $\begin{array}{c}\text { Total } \\
\text { +/total (\%) }\end{array}$ & P value \\
\hline $3 \mathrm{~m}+1 \mathrm{y}$ & $0 / 8$ & $0 / 5$ & $0 / 13$ & 0.1244 \\
$1 \mathrm{y}+3 \mathrm{y}$ & $8 / 14(57.1)$ & $7 / 16(43.7)$ & $15 / 30(50)$ & 0.0909 \\
$3 y+6 y$ & $7 / 21(33.3)$ & $4 / 9(44.4)$ & $11 / 30(36.7)$ & $0.0082^{*}$ \\
$>6 y$ & $4 / 16(25)$ & $1 / 14(7.1)$ & $5 / 30(16.7)$ & 0.1538 \\
Total & $19 / 59(32.2)$ & $12 / 44(27.3)$ & $31 / 103(30.1)$ & \\
\hline
\end{tabular}

$\mathrm{m}$ - months, $\mathrm{y}$ - years. Fisher Test $\mathrm{P}<0,05^{*}$.

From positive samples, 16/20 (80\%) were diagnosed by all optical microscopy and molecular techniques. In all PCR-positive samples, microfilariae were detected by means of microscopic observation. PCR was negative in 4/20 microfilaremic samples.

The thick smear evaluation (TS) and modified Knott's test (MK) showed excellent concordance $(K=1)$. The concordance between the other microfilarial detection tests was also high: i) between the wet fresh blood (WFB) and thin smear (TNS) evaluations ( $K=0.96$ ); ii) between WFB and TS (K=0.95); iii) between WFB and MK ( $K=0.95)$; between TNS and MK (K = 0.89); and between TS and TNS $(K=0.89)$. The overall concordance between the microfilarial detection tests and the molecular technique was substantial $(K=0.79)$.

Through ELISA Snap 4Dx, antigens were detected in 30/103 samples (29.1\%). In 11/103 (10.6\%), the diagnosis was made exclusively using ELISA and in 1/103 (0.9\%) only through microscopic parasitological techniques (WFB, TS and MK). Out of the 30 ELISA-positive samples, 
14 (13.5\%) were negative according to PCR (Table 2). Table 2 shows the results of the comparison among microscopic, immunological and molecular parasitological techniques.

Table 2. Results regarding positivity for canine filariids through four microscopic parasitological techniques, PCR and ELISA (Snap ${ }^{\mathrm{TM}}$ 4Dx ${ }^{\circledR}$ ) on blood samples from 31 dogs in Cabo Frio, RJ, Brazil.

\begin{tabular}{cccccc}
\hline $\begin{array}{c}\text { Microscopic } \\
\text { parasitological } \\
\text { techniques } \\
\text { positive }\end{array}$ & $\begin{array}{c}\text { PCR1/3+ and } \\
\text { ELISA+ } \\
(\mathbf{n}=16)\end{array}$ & $\mathbf{P *}$ & $\begin{array}{c}\text { PCR1/3- and } \\
\text { ELISA- } \\
(\mathbf{n}=\mathbf{1})\end{array}$ & $\begin{array}{c}\text { PCR1/3- and } \\
\text { ELISA+ }(\mathbf{n}=\mathbf{1 4})\end{array}$ & $\begin{array}{c}\text { Total } \\
(\mathbf{n}=\mathbf{3 1})\end{array}$ \\
\hline WFB & 16 & 0.250 & 1 & 3 & 20 \\
TNS & 16 & 0.625 & 0 & 2 & 18 \\
TS & 16 & 0,125 & 1 & 3 & 20 \\
MK+ & 16 & 0.125 & 1 & 3 & 20 \\
\hline
\end{tabular}

WFB - wet fresh blood, TNS - thin smear, TS - thick smear, MK - modified Knott technique, PCR1 - polymerase chain reaction, PCR3 - polymerase chain reaction double sample, ELISA - Snapp 4Dx ${ }^{\circledR}$ IDEXX, McNemar- P $<0.05^{*}$ association between microscopic parasitological techniques and PCR1/3+ and ELISA +.

Amplification of the mitochondrial region of the COI gene resulted in a single band of $203 \mathrm{bp}$ in samples 16/103 (15.5\%) (Figure 1). None of the samples negative for microfilariae showed amplification of the DNA fragment. Eight samples, that were positive according to microscopic parasitological techniques, were negative in the first PCR (PCR1). In PCR 2, these eight samples showed positivity, thus indicating absence of inhibitors of DNA amplification. PCR3 showed positivity in 4/8 samples, while 4/8 remained negative. After this attempt, DNA from the four negative samples was reextracted and PCR3 was repeated without amplification (Table 3).

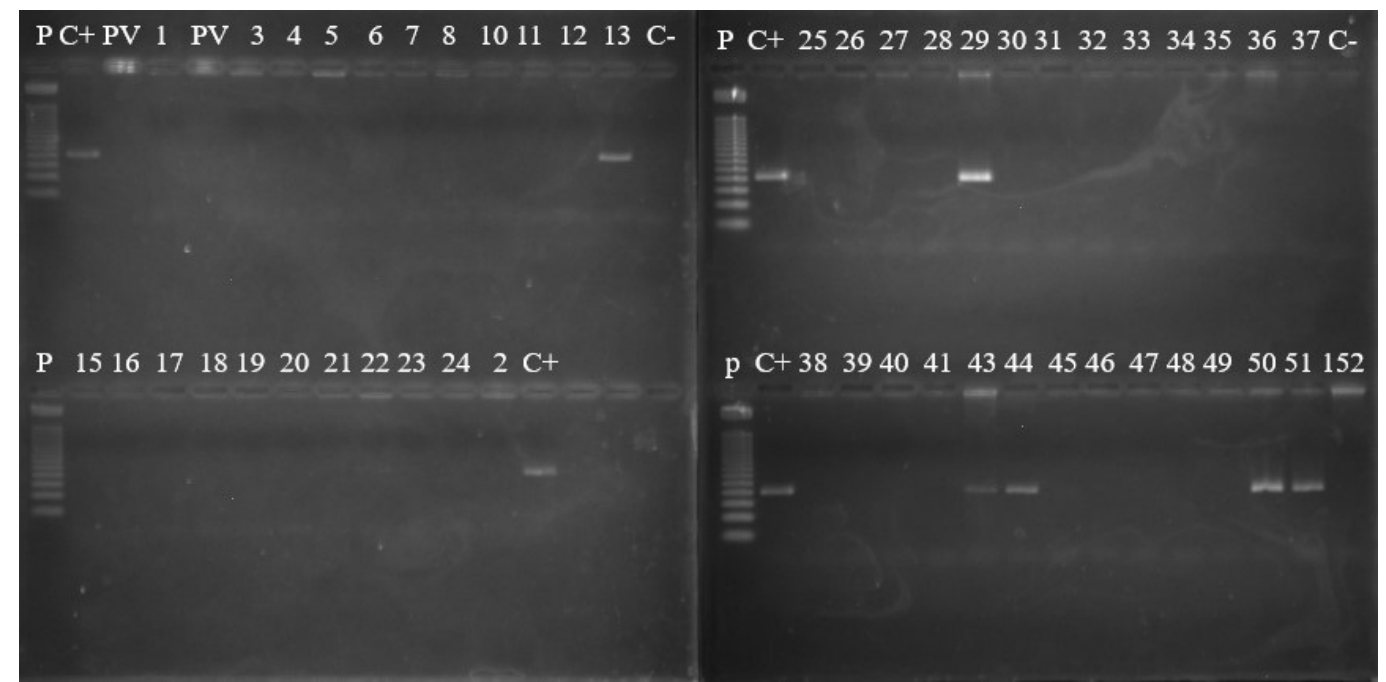

Figure 1. Product from $P C R$ using $\mathrm{COI} R$ and $\mathrm{COI} F$ primers, subjected to electrophoresis on $1.5 \%$ agarose gel: 1) DNA ladder (50 bp); C+) positive control with adult parasite DNA; PV) empty well; 1 Source: present authors. 
Table 3. Results from samples that were microfilaremic after using different polymerase chain reaction procedures, and results from sequencing four samples from dogs in Cabo Frio, RJ, Brazil.

\begin{tabular}{lccccc}
\hline \multicolumn{1}{c}{ Samples positive } & PCR 1 & PCR 2 & PCR 3 & PCR 4 & Sequenced sample \\
\hline 13 & + & ND & NR & NR & D. immitis \\
$29,43,44,50,51,52,63,68,73,87,149$ & + & ND & ND & ND & ND \\
$32,70,106$ & - & + & - & + & A. reconditum \\
115 & - & + & + & ND & ND \\
127 & - & + & - & - & - \\
$135,138,147$ & - & + & + & ND & ND \\
TOTAL & 12 & 8 & 4 & 3 &
\end{tabular}

PCR1 - primer COI, PCR2 - primer COI + parasite antigens, PCR3 - primer COI + double sample, PCR4 - panfilarial primer. ND = Not Done; - = not amplified sample; + = amplified sample.

After failure of PCR3 to show any positivity in these four samples, another PCR (PCR4) was performed using a panfilarial primer (DIDR), in order to investigate the possibility of presence of some other filariid and also to attempt to use another sequence for amplification of D. immitis. In this PCR4, there was amplification of three samples $(106,70,32)$ with bands around 500 to $600 \mathrm{bp}$, i.e. slightly above the positive control for $D$. immitis and compatible with another filariid: Acanthocheilonema reconditum. These three samples were then sequenced, and the presence of $A$. reconditum DNA was confirmed (Table 4).

Table 4. Results according to microscopic parasitological techniques, PCR and ELISA (Snap ${ }^{\mathrm{TM}}$ 4Dx ${ }^{\circledR}$ ) among positive blood samples to canine filariids from dogs in Cabo Frio, RJ, Brazil.

\begin{tabular}{lccc}
\hline \multicolumn{1}{c}{ Samples } & $\begin{array}{c}\text { Microscopic } \\
\text { parasitological } \\
\text { techniques }\end{array}$ & $\begin{array}{c}\text { ELISA } \\
\text { SNAP 4Dx }\end{array}$ & PCR \\
\hline $4,22,30,40,45,59,69,83,90,92,104$ & - & + & - \\
$13,29,43,44,50,51,52,63,68,73,87$, & + & + & + \\
$115,135,138,147,149$ & + & + & $+*$ \\
$32,70,106$ & + & + & - \\
127 & + & +
\end{tabular}

+ = positive, - = negative, $\mathrm{PCR}+=$ Dirofilaria immitis only, $\mathrm{PCR}+{ }^{*}=$ Acanthocheilonema reconditum only.

Sequencing of the amplified fragments of the adult parasite and a PCR-positive sample (sample 13) was performed and compared with the Dirofilaria immitis genotype (KC985239; Víchová et al., 2014) deposited in GenBank, with total homology (GenBank accession number: MG912908).

\section{Discussion}

The frequency of detection of microfilariae (19.4\%) was somewhat lower than what was reported by Labarthe et al. (1997) that showed 33.3\%. Variation in prevalence over the past 40 years may be associated with chemoprophylaxis or great owner sensitization. In recent large surveys, the frequency of detection of microfilariae has rarely been reported, since antigen detection tests have been used in recent reports. The present ELISA results of $29.1 \%$ was different of describe previous $27.5 \%$ in the results from the same area using immunochromatography antigen testing (Labarthe et al., 2014) and showed that although 
there seems to have been a slight increase in prevalence based on antigen detection over the years, the absolute numbers of infected dogs in the area is consistently high and represents a health threat to unprotected dogs living in the same area. The difference in frequency observed in relation to the other authors could be related to the lower number of animals previously studied, to the time when the blood samples were collected or to the use of immunological techniques that are able to detect hidden infection.

The age group with the highest frequency of positivity was from 3 to 6 years, and this group showed a statistically significant difference in relation to other age groups. The higher frequency in this age group might be associated with the development time of filariids (as observed in previous studies) which favors the diagnosis due to the existence of parasites in the microfilaremic productive phase, and to the longer time of exposure of the dogs to vector blood meals which favors the infection. This was also seen in other studies (Montaño et al., 2002; Byeon et al., 2007; Bolio-Gonzalez et al., 2007; Morchón et al., 2012). Higher positivity for heartworm infection was observed among male dogs, but without any significant difference. This information has also been reported outside of Brazil (Duran-Struuck et al., 2005; Brito et al., 2001).

The results obtained through the four microscopic parasitological techniques and those from PCR were found to be in agreement. There were similar findings from an evaluation on samples from dogs on the island of Marajó that were investigated regarding heartworm infection by means of microscopic parasitological techniques diagnosis for heartworm infection, in which the agreement between the results was associated with high parasite loads (Garcez et al., 2006). Among the dogs of the present study in Cabo Frio a total agreement of the results obtained through the modified Knott and thick smear evaluations and through the substantial agreement between the other microscopic parasitological techniques and PCR, as well as from the results of the McNemar test, could be associated with high parasitic load, although it has not been evaluated.

Evaluation of wet fresh blood slides showed positivity for microfilariae in 19/20 samples (95\%). There was discrepancy of positivity regarding one animal, compared with the findings from modified Knott and thick smear evaluations. Discrepant results among microscopic parasitological techniques were found in a study on dogs in Portugal, with lower frequency of positive samples in wet fresh blood evaluations (19.4\%) than in the results from the modified Knott's test (20.1\%) (Vieira et al., 2014).

The thin smear evaluation showed positivity in $90 \%(18 / 20)$ of the samples, and this was the technique through which numerically least effectiveness was reached, compared with the others. Among studies comparing the diagnostic techniques for heartworm disease that we retrieved, none of the authors used this technique for this purpose. Failure to use thin smears in studies may be related to the small amount of blood that is used in this procedure, which in areas of low parasitic load may give rise to false negative results.

The thick smear evaluation and the modified Knott technique showed agreement for all the samples in the present study. In some studies (Garcez et al., 2006; Larsson, 1990; Araújo et al., 2003) in which MK was used to obtain the microscopic parasitological diagnosis, the results were similar to or lower than those from thick-smear evaluations. Despite the high agreement among microscopic parasitological techniques, TS and MK found the largest numbers of positive dogs. This may have been related to the greater volume of blood used in the technical procedure and the concentration of parasite evolutionary forms, associated with fixation and staining, which favors identification.

Taking into account the technical procedure, it has been proven that TS is an appropriate technique, in high-frequency areas. MK requires a centrifuge and it has been recommended in the literature that centrifugation should be performed one day to three days (Fernandes et al., 1999) after sample collection. TS not only uses smaller amounts of sample but also can be done directly in the field, while generating a permanent slide that can be read later on and even be reread, without risk of loss of material, as well as enabling morphological evaluation. 
PCR showed that $15.5 \%(16 / 103)$ of the samples were positive, which was lower than the proportion found through microscopic parasitological techniques. These findings differed from those reported by Hou et al. (2011), Simsek et al. (2011) and Bamorovat et al. (2017), who observed better results through PCR. Ogawa et al. (2013) in Porto Velho, Rondônia, Brazil, showed that 12.8\% (93/727) of the dogs that they evaluated were positive according to immunoassay, $0 \%$ through the thick smear test and $10 \%(73 / 727)$ through PCR. Borthakur et al. (2015) in India obtained better efficiency through PCR (13.93\%) than through microscopic parasitological techniques (11.38\%), but with lower results than those obtained through ELISA (18.03\%). Similar results were also obtained by Bamorovat et al. (2017). The lower positivity through PCR in the present study was correlated with absence of microfilarial DNA in the aliquots. Borthakur et al. (2015) pointed out that the benefit of PCR would be that it enabled species differentiation. This was shown in the present study through identification of $A$. reconditum infection in three animals. In all microscopically negative samples of the present study, there was no amplification of $D$. immitis DNA, which confirms the specificity of PCR (Gioia et al., 2010). In the present study, there were no significant differences between the microscopic and molecular parasitological techniques, and all samples that were positive through PCR were also positive through at least one of the microscopic parasitological techniques. These results suggest that PCR positivity may be directly related to the presence of circulating microfilariae, even in small amounts.

Four samples were negative according to PCR. In two of these cases, this may have been due to small quantities of microfilariae. The aliquots prepared from these samples may thus have had no microfilariae or very few of them, and consequently little or no $D$. immitis DNA, which would make detection impossible.

Another possible for negativity could be the presence of a different parasite, as confirmed in the present study. In three samples in which parasite DNA was amplified using a panfilarial primer of 500 to $600 \mathrm{bp}$, sequencing showed that Acanthocheilonema reconditum DNA was present.

In two samples with microfilariae, PCR negativity may have occurred due to difficulty in amplifying DNA using the COI gene primer. Use of primers for other gene targets might resolve this issue, although the $\mathrm{COI}$ gene primer demonstrates greater consistency (Ferri et al., 2009). In addition, failure of DNA extraction, as reported by Borthakur et al. (2015), cannot be disregarded. In the present study, this was surmounted through repetition of the extraction procedure. Sequencing of the amplified fragments was done in one sample only to confirm whether the primers were amplifying nucleotide fragments specific for $D$. immitis.

Among the 103 samples, 30 (29.1\%) were positive according to ELISA (Snap 4Dx ${ }^{\circledR}$ ), but 11 of these (10.6\%) were negative according to microscopic parasitological techniques, thus showing that heartworm disease was hidden. Similar situations were described by Larsson et al. (1992) and Roth et al. (1993) and Bamorovat et al. (2017). Negativity of parasitological techniques while immunological techniques are positive has been correlated with temporary sterility of adults due to continuous therapy, use of microfilaricidal medication or monosexual infections (Roth et al., 1993). A substantial concordance index was obtained among all the techniques: $K=0.71$ between direct examination and ELISA and $\mathrm{K}=0.6494$ between modified Knott and ELISA.

In one animal of the present study that was positive for microfilariae, the ELISA showed negative results. A similar case was reported by Montaño et al. (2002), and a correlation was made with low levels of free antigens due to formation of immunocomplexes, immaturity of adult parasites or death of adults with persistence of microfilariae. Death of adults with persistence of microfilariae was also pointed out by Vieira et al. (2014). Negativity of samples through ELISA and positivity through microscopic techniques, thus suggesting the possibility of infection by a filariid species other than D. immitis, was also reported by Duran-Struuck et al. (2005). Despite such situations, use of ELISA in serological diagnosis heartworm disease has become mandatory. 
The rate of positivity through PCR (15.5\%) was lower than through ELISA (29.1\%) in the present study. This was also observed by Borthakur et al. (2015), who found positivity through ELISA of $18.03 \%$, while it was only $13.93 \%$ through PCR. This was correlated with hidden infection or DNA extraction failure. Three out of the four samples that were negative according to PCR1, showed positivity through ELISA and PCR4 (panfilarial primer). This might be related to co-infection with $D$. immitis and $A$. reconditum, possibly associated with a low burden of $D$. immitis microfilariae that was undetectable in PCR1. In one sample, only PCR4 was positive, thus suggesting single infection by $A$. reconditum. Torres-Chable et al. (2018) pointed out that is important to assay for other filarial nematodes, including inconsequential pathogens, to minimalize the likelihood of misdiagnosis that commonly occurs when using the Knott's test if species differentiation is not considered.

In this study, PCR with the COI gene did not present applicability for routine diagnosing of canine heartworm disease, in comparison with the other techniques used, despite the small panel of positive samples. In addition, its high cost, processing time, infrastructure and specialized labor limits its use. Nevertheless, it can be performed as a preliminary step in diagnosing species, in cases of molecular epidemiology studies, or as an auxiliary tool for aiding ELISA in areas of low parasite frequency. It is necessary to expand these studies, with larger numbers of samples, covering different locations, and with use of different molecular targets, especially in cases in which microscopy is inconclusive, as done in the present study, thereby confirming the species that had been detected.

The ELISA (Snap 4Dx ${ }^{\circledR}$ ) enabled detection of hidden infections. This highlights the importance of its use in diagnostic procedures investigating presence of this parasite in clinical and epidemiological studies. It should be noted that, despite the greater efficiency of this immunological technique, it is important that, whenever possible, a microscopic parasitological technique such as thick smear or modified Knott should be used in association with ELISA, to increase the diagnostic accuracy. There was one sample in the present study for which the diagnosis was made solely through thick smear or modified Knott parasitological techniques.

\section{Conclusions}

It was possible to detect $D$. immitis infection among dogs in Cabo Frio, RJ, Brazil, through parasitological techniques using microscopy, immunological techniques for antigen research and molecular techniques through the polymerase chain reaction. Excellent agreement was obtained between the four parasitological techniques that used microscopy. Substantial agreement was obtained between parasitological techniques through microscopy, ELISA and PCR. The thick smear and modified Knott evaluations were seen to be the parasitological techniques with greatest numerical effectiveness, compared with the other parasitological techniques. ELISA was more effective in serological diagnosis of heartworm.

\section{References}

Araujo RT, Marcondes CB, Bastos LC, Sartor DC. Canine dirofilariasis in the region of Conceição Lagoon, Florianópolis, and in the Military Police kennel, São José, State of Santa Catarina, Brazil. Vet Parasitol 2003; 113(3-4): 239-242. http://dx.doi.org/10.1016/S0304-4017(03)00077-3. PMid:12719138.

Atkins CE. Comparison of results of three commercial heartworm antigen test kits in dogs with low heartworm burdens. J Am Vet Med Assoc 2003; 222(9): 1221-1223. http://dx.doi.org/10.2460/javma.2003.222.1221. PMid:12725308.

Bamorovat M, Sharifi I, Fasihi Harandi M, Nasibi S, Sadeghi B, Khedri J, et al. Parasitological, Serological and Molecular Study of Dirofilaria immitis in Domestic Dogs, Southeastern Iran. Iran J Parasitol 2017; 12(2): 260-266. PMid:28761487. 
Bolio-Gonzalez ME, Rodriguez-Vivas RI, Sauri-Arceo CH, Gutierrez-Blanco E, Ortega-Pacheco A, ColinFlores RF. Prevalence of the Dirofilaria immitis infection in dogs from Merida, Yucatan, Mexico. Vet Parasitol 2007; 148(2): 166-169. http://dx.doi.org/10.1016/j.vetpar.2007.05.019. PMid:17630215.

Borthakur SK, Deka DK, Islam S, Sarma DK, Sarmah PC. Prevalence and molecular epidemiological data on Dirofilaria immitis in dogs from Northeastern States of India. ScientificWorldJournal 2015; 2015: 265385. http://dx.doi.org/10.1155/2015/265385. PMid:25685835.

Brito AC, Vila-Nova MC, Rocha DAM, Costa LG, Almeida WAP, Viana LS, et al. Prevalência da filariose canina causada por Dirofilaria immitis e Dipetalonema reconditum em Maceió, Alagoas, Brasil. Cad Saude Publica 2001; 17(6): 1497-1504. http://dx.doi.org/10.1590/S0102311X2001000600021. PMid:11784911.

Byeon KH, Kim BJ, Kim SM, Yu HS, Jeong HJ, Ock MS. A serological survey of Dirofilaria immitis infection in pet dogs of Busan, Korea, and effects of chemoprophylaxis. Korean J Parasitol 2007; 45(1): 27-32. http://dx.doi.org/10.3347/kjp.2007.45.1.27. PMid:17374975.

De Carli GA. Parasitologia Clínica: seleção de métodos e técnicas de laboratório para o diagnóstico das parasitoses humanas. 1st ed. São Paulo: Editora Atheneu; 2001.

Dillon AR, Blagburn BL, Tillson DM, Brawner WR, Welles B, Johnson C, et al. Immature heartworm infection produces pulmonary parenchymal, airway and vascular disease in cats. J Vet Intern Med 2007; 21(3): 608-609.

Duran-Struuck R, Jost C, Hernandez AH. Dirofilaria immitis prevalence in a canine population in the Samana Peninsula (Dominique Republic) - June 2001. Vet Parasitol 2005; 133(4): 323-327. http://dx.doi.org/10.1016/j.vetpar.2005.06.008. PMid:16023785.

Fernandes CGN, Moura ST, Dias AR, Vieira Filho WS. Ocorrência de dirofilariose canina na região da Grande Cuiabá, Estado do Mato Grosso - Brasil. Braz J Vet Res Anim Sci 1999; 36(5): 145-150. https://doi.org/10.1590/S1413-95961999000500007.

Ferri E, Barbuto M, Bain O, Galimberti A, Uni S, Guerrero R, et al. Integrated taxonomy: Traditional approach and DNA barcoding for the identification of filarioid worms and related parasites (Nematoda). Front Zool 2009; 6(1): 1-29. http://dx.doi.org/10.1186/1742-9994-6-1. PMid:19128479.

Garcez LM, Souza NF, Mota EF, Dickson LAJ, Abreu WU, Cavalcanti VFN, et al. Focos de dirofilariose canina na Ilha do Marajó: um fator de risco para a saúde humana. Rev Soc Bras Med Trop 2006; 39(4): 333-336. http://dx.doi.org/10.1590/S0037-86822006000400003. PMid:17119746.

Gioia G, Lecová L, Genchi M, Ferri E, Genchi C, Mortarino M. Highly sensitive multiplex PCR for simultaneous detection and dis-crimination of Dirofilaria immitis and Dirofilaria repens in canine peripheral blood. Vet Parasitol 2010; 172(1-2): 160-163. http://dx.doi.org/10.1016/j.vetpar.2010.04.027. PMid:20483540.

Hou H, Shen G, Wu W, Gong P, Liu Q, You J, et al. Prevalence of Dirofilaria immitis infection in dogs from Dandong, China. Vet Parasitol 2011; 183(1-2): 189-193. http://dx.doi.org/10.1016/j.vetpar.2011.06.016. PMid:21889850.

Knott J. A method for making microfilarial surveys on day blood. Trans R Soc Trop Med Hyg 1939; 33(2): 191-196. http://dx.doi.org/10.1016/S0035-9203(39)90101-X.

Labarthe N, Almosny N, Guerrero J, Duque-Araújo AM. Description of the occurrence of canine dirofilariosis in the State of Rio de Janeiro, Brazil. Mem Inst Oswaldo Cruz 1997; 92(1): 47-51. http://dx.doi.org/10.1590/S0074-02761997000100010. PMid:9302414.

Labarthe N, Campos-Pereira MC, Barbarini O, McKee W, Coimbra CA, Hoskins J. Serologic Prevalence of Dirofilaria immitis, Ehrlichia canis, and Borrelia burgdorferi Infections in Brazil. Vet Ther 2003; 4(1): 67-73. PMid:12756637.

Labarthe N, Paiva JP, Reifur L, Mendes-de-Almeida F, Merlo A, Pinto CJC, et al. Updated canine infection rates for Dirofilaria immitis in areas of Brazil previously identified as having a high incidence of heartworm-infected dogs. Parasit Vectors 2014; 7(1): 493. http://dx.doi.org/10.1186/s13071-014-0493-7. PMid:25376238.

Landis JR, Koch GG. The measurement of observer agreement for categorical data. Biometrics 1977; 33(1): 159-174. http://dx.doi.org/10.2307/2529310. PMid:843571. 
Larsson MHNA, Preterote M, Mirandola RMS. Diagnóstico de dirofilariose oculta pelo teste de ELISA, em cães do Estado de São Paulo. Braz J Vet Res Anim Sci 1992; 29(1): 93-96. http://dx.doi.org/10.11606/issn.1678-4456.bjvras.1992.51957.

Larsson MHMA. Prevalência de microfilárias de Dirofilaria immitis em cães do Estado de São Paulo. Braz J Vet Res Anim Sci 1990; 27(2): 183-186. http://dx.doi.org/10.11606/issn.0000-0000.272183186.

López J, Valiente-Echeverria F, Carrasco M, Mercado R, Abarca K. Identificación morfológica y molecular de filarías caninas en una comuna semi-rural de la Región Metropolitana, Chile. Rev Chilena Infecto/ 2012; 29(3): 284-289. http://dx.doi.org/10.4067/S0716-10182012000300006. PMid:23096462.

McCall JW, Genchi C, Kramer LH, Guerrero J, Venco L. Heartworm disease in animals and humans. Adv Parasito/ 2008; 66: 193-285. http://dx.doi.org/10.1016/S0065-308X(08)00204-2. PMid:18486691.

McCall JW, Guerrero J, Genchi C, Kramer L, Bazzocchi C, Simon F, et al. Recent advances in heartworm disease. Vet Parasitol 2004; 125(1-2): 105-130. http://dx.doi.org/10.1016/j.vetpar.2004.05.008. PMid:24937882.

Montaño JMF, Alvarado CMA, Morillo MA, Martínez JES. Diagnóstico de dirofilariosis canina: un estudio comparativo usando las pruebas de ELISA y de Woo. Rev Cient FCV-LUZ 2002; 12(5): 351358.

Morchón R, Carréton E, González-Miguel J, Mellado-Hernández I. Heartworm disease (Dirofilaria immitis) and their vectors in Europe - new distribution trends. Front Physiol 2012; 3: 196. http://dx.doi.org/10.3389/fphys.2012.00196. PMid:22701433.

Newton WL, Wright WH. The occurrence of a dog filariid other than Dirofilaria immitis in the United States. J Parasitol 1956; 42(3): 246-258. http://dx.doi.org/10.2307/3274849. PMid:13332492.

Ogawa GM, Cruz EN, Cunha PNA, Camargo LMA. Canine heartworm disease in Porto Velho: first record, distribution map and occurrence of positive mosquitoes. Rev Bras Parasitol Vet 2013; 22(4): 559-564. http://dx.doi.org/10.1590/S1984-29612013000400017. PMid:24473882.

Rishniw M, Barr SC, Simpson KW, Frongillo MF, Franz M, Dominguez Alpizar JL. Discrimination between six species of canine microfilariae by a single polymerase chain reaction. Vet Parasitol 2006; 135(3-4): 303-314. http://dx.doi.org/10.1016/j.vetpar.2005.10.013. PMid:16289566.

Roth L, Brown L, Brum S, Foster L, Nelson M, Reczeck D, et al. Comparison of three Diagnostic Tests for Dirofilaria immitis in a Low-Incidence Area.J Vet Diagn Invest 1993; 5(4): 647-648. http://dx.doi.org/10.1177/104063879300500431. PMid:8286476.

Simsek S, Ozkanlar Y, Balkaya I, Aktas MS. Microscopic, serological and molecular surveys on Dirofilaria immitis in strain dogs, Turkey. Vet Parasitol 2011; 183(1-2): 109-113. http://dx.doi.org/10.1016/j.vetpar.2011.06.012. PMid:21757293.

Todd KS Jr, Howland TP. Transplacental Transmission of Dirofilaria immitis Microfilariae in the dog. J Parasitol 1983; 69(2): 371. http://dx.doi.org/10.2307/3281237. PMid:6854475.

Torres-Chable OM, Baak-Baak CM, Cigarroa-Toledo N, Blitvich BJ, Brito-Argaez LG, Alvarado-Kantun YN, et al. Molecular detection of Dirofilaria immitis in dogs and mosquitoes in Tabasco, Mexico.J Vector Borne Dis 2018; 55(2): 151-158. http://dx.doi.org/10.4103/0972-9062.242563. PMid:30280714.

Víchová B, Miterpáková M, Iglódyová A. Molecular detection of co-infections with Anaplasma phagocytophilum and/or Babesia canis canis in Dirofilaria-positive dogs from Slovakia. Vet Parasitol 2014; 203(1-2): 167-172. http://dx.doi.org/10.1016/j.vetpar.2014.01.022. PMid:24630708.

Vieira AL, Vieira MJ, Oliveira JM, Simões AR, Diez-Baños P, Gestal J. Prevalence of canine heartworm (Dirofilaria immitis) disease in dogs of central Portugal. Parasite 2014; 21: 1-20. http://dx.doi.org/10.1051/parasite/2014003. PMid:24534524. 